\title{
CHARACTERIZATION OF LEAVES AND FRUITS OF MANGO (Mangifera indica L.) CV. IMBU ${ }^{1}$
}

\author{
JULIANA CRISTINA VIECCELLI ${ }^{2}$, DALMO LOPES DE SIQUEIRA ${ }^{3}$, \\ WILKA MESSNER DA SILVA BISPO ${ }^{4}$, LORENA MOREIRA CARVALHO LEMOS
}

ABSTRACT - Although mango is one of the tropical fruits of greater interest in world trade, literature concerning their rootstocks (characteristics and utilization) is scarce. This study aimed to characterize mango plants from cv. Imbú, widely used as rootstock in the Zona da Mata region, Minas Gerais (MG), Brazil. Though fruits of this cultivar do not present desirable commercial characteristics, this study allowed us to characterize part of plant morphology and fill a gap in the literature, providing subsidies for future investigations. For such, 'Imbú' plants $(\approx 4$-years old) from the collection of the Universidade Federal de Viçosa, located in Viçosa -MG were evaluated. The descriptors were: (i) leaf blade division;(ii) leaf composition; (iii) petiole length in relation to leaf blade; (iv) phyllotaxis, (v) leaf position in relation to the branch insertion; (vi) leaf shape; (vii) leaf apex and base angles; (viii) leaf margin category; (ix) venation; (x) leaf length and thickness; (xi) leaf length/thickness ratio; (xii) leaf texture; (xiii) leaf fragrance; (xix) leaf color. The leaves were depicted as lanceolate, with entire margins and sharp angles at the base and apex of the leaf blade. The intensity of the green color of the leaf blade was considered intermediate and the abaxial surface staining showed less intense than that observed in the upper side. The fruits were processed and separated into peel, pulp and seeds in order to evaluate the flesh color, fresh weight and percentage of seeds, peel and pulp. Was determined the soluble solids content, starch concentration, the peel and the pulp color, the cerosity, the percentage evaluation of peel, pulp and seed and the pulp firmness. The average number of germinated seedlings per seed was estimated for 230 sown seeds.

Index terms: Rootstock, Mangifera indica, morphology

\section{CARACTERIZAÇÃO DE FOLHAS E FRUTOS DA MANGUEIRA (Mangifera indica L.) CV. IMBÚ}

\begin{abstract}
RESUMO - Apesar de a manga ser uma das frutas tropicais de maior interesse no comércio mundial, a literatura sobre os seus porta-enxertos (características e utilização) é escassa. Este estudo teve como objetivo caracterizar as mangueiras da cv. Imbu, amplamente utilizada como porta-enxerto na região da Zona da Mata de Minas Gerais (MG), Brasil. E, embora frutos dessa cultivar não apresentem características comerciais desejáveis, este estudo permitiu caracterizar parte da morfologia da planta e preencher uma lacuna na literatura, fornecendo subsídios para futuras investigações. Para tal, folhas completamente expandidas da porção mediana de ramos expostos à luz solar e frutos plenamente desenvolvidos foram coletados de plantas da cv. 'Imbu' $(\approx 4$ anos de idade) da coleção da Universidade Federal de Viçosa, localizada no município de Viçosa - MG. Os descritores foram: (i) divisão lâmina de folha; (ii) a composição da folha; (iii) comprimento do pecíolo em relação à lâmina de folha; (iv) filotaxia, (v) a posição das folhas em relação à inserção do ramo; (vi) a forma de folha; (vii) ângulos do vértice da folha e de base; (viii) categoria margem da folha; (ix) venação; (x) comprimento da folha e espessura; (xi) Relação espessura / comprimento da folha; (xii) textura da folha; (xiii) fragrância da folha; (xix) cor da folha. As folhas foram descritas como lanceoladas, com margens inteiras e ângulos afilados na base e ápice da lâmina de folha. A intensidade da cor verde da lâmina foliar foi considerada intermediária e a coloração da superfície abaxial mostrou menos intensa do que a observada no lado superior. Os frutos foram processados e separados em casca, polpa e sementes, a fim de avaliar a cor da polpa, o peso fresco e percentagem de sementes, casca e polpa. Foi determinado o teor de sólidos solúveis, concentração de amido, coloração da casca e da polpa, a cerosidade, a percentagem de casca, de polpa e de semente e a firmeza da polpa. O número médio de plântulas germinadas por semente foi estimado para 230 sementes semeadas.
\end{abstract}

Termos para indexação: Porta-enxerto, Mangifera indica, morfologia

'(Trabalho 104-15). Recebido em: 16-04-2015. Aceito para publicação em: 10-09-2015.

${ }^{2}$ Dra. Fitotecnia. Universidade Federal de Viçosa (UFV), Dept. Fitotecnia, Viçosa, MG- Brazil. E-mail: jcvieccelli@gmail.com

${ }^{3}$ Dr. Fitotecnia. UFV, Dept. Fitotecnia. E-mail: siqueira@ufv.br

${ }^{4}$ Dra. Fisiologia Vegetal. UFV, Dept. Biologia Vegetal. E-mail: wilka.messner@gmail.com

${ }^{5}$ Dra. Fitotecnia. UFV, Dept. Fitotecnia. E-mail: lorenamcarvalho@yahoo.com.br 


\section{INTRODUCTION}

Fruit growing is one of the most prominent segments in the Brazilian economy, with this sector among the main generators of income and employment, since Brazil ranks third in the world ranking of fruit production according to FAO (2013) and, among the more fruits produced in Brazil, there is mango due to the excellent conditions for its development and production. The country now accounts for a volume of production that exceeds 40 million tons, accounting for $5.7 \%$ of world production and ranking it as the third largest producer of fruits in the world (ANDRADE, 2012).

Due to its great adaptability, mango originated in Asia and has expanded in Brazil, mainly in the mid-1980s and throughout the 1990, where it has been cultivated in almost all regions of the country (ANDRADE, 2012).

The identification of rootstocks suited to different soil and climatic conditions of cultivation and its initial performance in different conditions of nursery, are of great interest in the production of seedlings sector (SCHMITZ et al., 2014). In order to install orchards with a high productive potential, it is essential to use seedlings free of pests and diseases and presenting recognized genetic potential. This procedure enables rapid and vigorous growth, generating plants with great architecture and with an intense and precocious productive life. The use of grafting technique play an important role in implementing orchards under such conditions, since it favors the driven connection between favorable characteristics for both production and disease resistance.

In mango both polyembryonic and monoembryonic rootstocks are used with only a few rootstock cultivars identified as conferring beneficial effects on scions. In recent times more of an effort has been put in to discovering and evaluation rootstocks for mango that deliver environmental adaptability, uniformity, vigour control or yield enhancement to scions. Rootstock evaluation and selection is on going in many countries and is likely to provide specific rootstock/scion combination that will enhance the production and quality performance of specific scions and help to even out annual fluctuations in production and quality (BALLY, 2011).

Worldwide, the rootstocks of most stone fruit are still propagated by seeds (MALCOLM et al., 2003). In Brazil, the rootstock is obtained almost exclusively based on the availability of seed.

It is highly recommended to give preference to local varieties that have small size and the polyembryonic cultivars, $i$. e. those generating two or more plants from a single seed, are the most suitable for this purpose, providing greater vigor to seedlings and the same mother-plant quality. In the Northeast Brazil, the cultivars Espada, Rosa, Carlota, Itamaracá and Coité are the most used, while in the States of Minas Gerais and São Paulo, the preference lies with cultivars Ubá, Sapinho, Coquinho, Rosinha, Espada and Coração-de-boi. The cultivars 'Espada' and 'Jasmin' have wide acceptance among nurserymen not only due to its natural vigor, but also by its tolerance against the mango wilt, a fungal disease that affects orchards mainly in São Paulo (CASTRO NETO; CUNHA, 2000).

Other mango cultivars, such as cv. Imbú, have also been explored as rootstocks. 'Imbú' plants are often chosen by their easiness in removing the cored seeds, the vigorous growth of the plants and the fact that it is a polyembrionic cultivar. Although not used in all producing areas of the country, is virtually the only rootstock used by nurseries and mango orchards in the Zona da Mata region, Minas Gerais, Brazil. In this region, for instance, the cultivation of mango plants from cv. Ubá (often grafted in 'Imbú') has been widely stimulated, as it has desirable characteristics for use in processing industries, such as high content of soluble solids, attractive color and flavor and few fibers (BENEVIDES et al., 2008). Thus, cv. Imbú presents increasing forecasts as a rootstock variety, especially due to the increasing development of the cultivated area.

Although of recognized importance, studies concerning the cultivars that are not employed as 'crown varieties' are scarce. In the case of cv. Imbú, nearly nothing is known regarding either morphology or physiology, despite its consistent use in plantations and nurseries in Brazil. This way, considering both the importance of mango plants to the Brazilian fruit production (and its growing foreign demand) and the lack of reliable information about rootstock cultivars, this study aimed to characterize mango plants from cv. Imbú, in order to fill a gap in the literature and instigate and assist future and deeper research. According to the International Board for Plant Genetic Resources (1988), cultivar characterization is an essential step in certification programs, breeding works and germplasm conservation, allowing the monitoring and conservation of genetic quality.

\section{MATERIAL AND METHODS}

Plant material. This study was performed in four-year-old mango plants from cv. Imbú, belonging 
to the collection of the Universidade Federal de Viçosa, located in Viçosa, Minas Gerais, Brazil. For leaf analyzes, five fully developed leaves from the middle third of branches exposed to sunlight were collected. Ten fruits were collected per plant. For such descriptions, four fully developed plants were used as evaluation units (RIBEIRO et al., 2013).

Tree descriptors. The trees growth habit was observed directly in the field, according to the previously proposed descriptors (IPGRI, 2006), classifying them as vertical, vertical to semi-vertical, semi-vertical to open and open.

Leaf descriptors. Leaf description was largely performed as previously described (IPGRI, 2006). The descriptors were: (i) leaf blade division;(ii) leaf composition; (iii) petiole length in relation to leaf blade; (iv) phyllotaxis, (v) leaf position in relation to the branch insertion; (vi) leaf shape; (vii) leaf apex and base angles; (viii) leaf margin category; (ix) venation; (x) leaf length and thickness; (xi) leaf length/thickness ratio; (xii) leaf texture; (xiii) leaf fragrance; (xix) leaf color.

Fruit descriptors. Physiologically mature fruits were harvested, transported to the laboratory and immersed in a sodium hypochlorite solution $100 \mathrm{~mL} \mathrm{~L}^{-1}$ for 5 minutes for surface sanitization and latex removing (OLIVEIRA et al., 2013). The criteria used to determine the harvest time were (i) peel color,(ii) fruit shape and (iii) filling of the shoulder region in relation to the stalk (GENÚ; PINTO, 2002). The overall description was largely performed as previously recommended (IPGRI, 2006). Fruits were processed and separated into peel, pulp and seeds in order to evaluate the flesh color, fresh weight and percentage of seeds, peel and pulp. The soluble solids content was determined with the aid of a portable refractometer Atago N1, with scale ranging from 0 to $53^{\circ}$ Brix. Starch concentration was determined from the remaining residue from ethanol extractions using the methodology described by McCready et al. (1950) and modified by Patel (1970). The peel color was evaluated by making two readings on opposite sides of the equatorial region of the fruit. The pulp color was measured by an internal reading at the central region. For that purpose, a Minolta colorimeter CR-10 was used, based on the values of $\mathrm{L}, \mathrm{C}$ and $\mathrm{h}^{\mathrm{o}}$. In standard C.I.E. L*a* $\mathrm{b}^{*}$, the $\mathrm{L}^{*}$ coordinate expresses the lightness degree of the color measurement $\left(\mathrm{L}^{*}=100=\right.$ white, $\mathrm{L}^{*}=0=$ black$)$; the $\mathrm{a}^{*}$ coordinate expresses the degree of variation between red and green colors (more negative $\mathrm{a}^{*}=$ greener, more positive $\mathrm{a}^{*}=$ redder); the $\mathrm{b}^{*}$ coordinate expresses the degree of variation between the blue and yellow colors (more negative $\mathrm{b}^{*}=$ bluer; more positive $b^{*}=$ yellower). The $h^{\circ}$ (hue angle) is calculated by: $h^{\circ}=\tan -1\left(b^{*} / a^{*}\right)$, ranging from 0 to $360^{\circ}$, with $0^{\circ}$ - red, $90^{\circ}$ - yellow, $180^{\circ}$ - green and $270^{\circ}$ - blue (McGUIRE, 1992; OLIVEIRA et al., 2013). Cerosity was evaluated by the verification of a whitened layer on the fruit (OLIVEIRA et al., 2013). The percentage evaluation of peel, pulp and seed was gravimetrically performed (OLIVEIRA et al., 2013). The pulp firmness was evaluated using a digital penetrometer (SHIMPO, model DFS100) with a tip (12mm in diameter) and the results were expressed in $\mathrm{N}$.

\section{RESULTS AND DISCUSSON}

According to Ribeiro et al. (2013), to date, from all registrations of mango varieties, only two of those protected by Ministry of Agriculture, Livestock and Supply (MAPA) have requirements for the International Union for the Protection of New Varieties of Plants descriptors (UPOV-descriptors): Shelly, from the State of Israel and TFE 02 from South Africa. Descriptors, however, are required for seedling production, certification and marketing. Cultivar characterization can be made based on plant morphology, consisting on the adoption of inheritable botanical descriptors, easily visible and, at least in principle, expressed in all environments (RIBEIRO et al., 2013). Thereby, to the best of author's knowledge, the present work adds new insights in cultivar characterization, presenting the first attempt to input information regarding the morphology of mango plants from cv. Imbú, thus encouraging further and deeper investigations.

General tree description. Mango trees are often leafy and present small to large size, reaching up to 30 meters (NETO, 2007). They feature rounded and symmetrical canopy, ranging from low and dense to erect and open, eventually getting a pyramidal shape. In modern plantations, however, the size and shape of the plant is determined by the density of planting and cultural practices, as the pruning system (NETO, 2007). At the present study, the evaluated 'Imbú' trees were considered short $(\leq 6 \mathrm{~m})$, with sparse foliage density and presented, predominantly, a semi-vertical progression. This growth habit greatly simplify orchard maintenance and bring further advantages such as increased lighting and aeration of the canopy, stimulating higher productivity (RIBEIRO et al., 2013).

Leaf description. The leaves from cv. Imbú were classified as simple (leaf blade is not divided), incomplete (with no sheath), petiolate (brevipetiolate) -with petioles length greater than $15 \mathrm{~mm}$ (on average 
$51,24 \mathrm{~mm})$ - and alternately arranged. The leaf position on the branch proved to be semi-erect in the appraised plants, being straight the petiole insertion into the branch. Pulvinus showed thin in relation to whole petiole. Leaves were depicted as lanceolate, presenting sharp angles (acute) at the base and apex of the leaf blade, and also presented margins totally devoid of division or striking ripples (entire margins). Moreover, protruding major veins were observed, especially at the abaxial epidermal surface. The angulation of the secondary veins towards the midrib proved to be medium (ranging from 45 to $60^{\circ}$ ) and secondary veins showed a slight curvature when approaching leaf edges.

The leaf length and width were, on average, respectively of $243.44 \mathrm{~mm}$ and $55.74 \mathrm{~mm}$. The data concerning the measures of the predominant leaves showed in close association with those found by Laroussilhe (1980) for other cultivars, with leaf length ranging from 150 to $400 \mathrm{~mm}$ and leaf width ranging from $15 \mathrm{~cm}$ to $40 \mathrm{~mm}$. The leaf length/width ratio had an average of 4.37 at the present study. Mature leaves were considered coriaceous in texture, free of pubescence and presented a mild fragrance when crushed.

As previously found for Mangifera indica (NETO et al., 2007; RIBEIRO et al., 2013), leaf color varies from light-green to slightly brownish or purplish when plants are young, and acquires a dark green color as it develops and become mature. Indeed, young leaves from cv. Imbú showed a reddish coloration that vanished as the leaf stretched. Also for this cultivar, the green color intensity of the mature leaf blade was considered intermediate, with an averaged SPAD index of 44.0. Polychromy was not verified. The color of the leaf abaxial surface was less intense than that observed in the upper leaf side (adaxial surface).

Fruit description. Mature trees from cv. Imbú showed medium to high fruit bearing intensity, comparable (in proportion) to cv. Tommy Atkins (COSTA; SANTOS, 2005). The evaluated fruits showed morphological characteristics similar to those presented by cv. Ubá, averaging $70 \mathrm{~mm}$ for longitudinal diameter and $55 \mathrm{~mm}$ for transverse diameter (RUFINI et al., 2011). The average fresh weight of $124.9 \mathrm{~g}$ (Table 1) characterizes 'Imbú' as a cultivar of small fruits, what discourages its acceptance in in natura market. Silva et al. (2009), when evaluating fifteen mango cultivars, found the highest and lowest fresh weight, respectively, for cvs. Tommy Atkins (521.1 g) and Soares Gouveia (130.8 g). The seed size in 'Imbú' fruits (slightly reniform shape) is greater than that observed in other varieties of mango plants, making up about $22.32 \%$ of the fruit body (Table 1). For comparison, seed percentages of 6.2 and $21 \%$ were previously found, respectively for cvs. Palmer and Zill (SILVA et al., 2009). Further, the fruits had an obovoid shape, with an obtuse apex. The slope of the fruits ventral shoulder ended in a long curve and, in the apical portion, a "beak" is barely noticeable, as well as a sinus. The fruit stalk insertion was vertical, with minor latex release when detaching it and the bond strength between stalk and fruit was moderate. The depth of fruit stalk cavity was considered shallow and was not observed a neck in the region of interaction between stalk and fruit.

There is in Brazil a great diversity of mango varieties. For fresh consumption, in addition to flavor characteristics, the fruit color, size and the overall look (free of marks from mechanical damage or due to biotic factors) are also considered (BUTAC et al., 2012). At last, mango rootstocks, just as those used in other cultures, are generally selected for traits such as resistance to drought, root pests, and diseases (SCHÄFER et al., 2001). Fruits from cv. Imbú had in general a poor attractiveness. Thus, considering the foregoing, they not seem proper for employment in the fresh consumption market. The fruit's skin showed scarcely waxy (poor brightness) and predominantly smooth. The peel background color presented yellow, with a slight orange blush. Unlike the observed in highly attractive cultivars such as Tommy Atkins and Palmer, this combination of colors seems to nor highlight or draw the consumers' attention, being preferred the red and pink colorations (BENEVIDES et al., 2008). The hue angle expresses differences in skin color and pulp, allowing the visualization of changes in the color of fruits along ripening (AZZOLINI et al., 2004). Considering the obtained b module $(49,16)$ and the pulp hue angle $(85,69)$ (Table 2), cv. Imbú pulp appears to be within the average values already found in other varieties, such as Ubá and Extrema (SILVA et al., 2009).

One of the most important factors concerning fruit conservation is the maintenance of firmness (ANDRADE JÚNIOR et al., 2001). The relationship between the degree of maturation and the postharvest fruit quality has been widely described and it is often reported that reduction in firmness leads to increased susceptibility to mechanical damage, decays, physiological alterations and, consequently, a shorter shelf-life (MARI et al. 2003; FISCHER et al, 2008). Regarding the firmness of mango fruits, Lederman et al. (1998) suggested that the ideal value should exceeds $90 \mathrm{~N}$ for a consistent postharvest longevity and a higher resistance to transportation. However, for fresh consumption should be noted that 
fruits that are softer in texture are preferred (GENU'; PINTO, 2002). Thus, in front of the obtained results, fruits from cv. Imbú would not fall as fruits for fresh consumption. Undoubtedly by the high concentration of fibers and poor juiciness, the 'Imbú' fruit pulp showed only a slightly soft texture and a high average value for firmness (Table 1). Fruits from cv. Imbú are not either suitable for industrial purposes, since the lack or reduction in fibers content is one of the requirements for mango processing by the industrial market in Brazil (BERNIZ, 1984).

Total soluble solids ( $\left.{ }^{\circ} \mathrm{Brix}\right)$ plays a key role in maintaining fruit quality, due to its influence on thermophysical, chemical and biological fruit properties (COSTA et al., 2004). The analysis of ${ }^{\circ}$ Brix is very important in the control of the ingredients to be added to a product during an industrial process and is often used in beverages or pastries industries (ARAÚJO, 2001; COSTA et al., 2004). The higher the amount of soluble solids, the smaller will be the amount of sugar added to a fruit pulp, for instance, when juices or nectars are being manufactured. Thus, the costs of production decreases, while increasing product quality (COSTA et al., 2004).
Legislation requires a minimum value of $11^{\circ} \mathrm{Brix}$ for a mango pulp to be suitable for industrial use (BENEVIDES et al., 2008). Therefore, according to this aspect, the evaluated fruits from cv. Imbú would not fulfill the requirements for industrial purpose. Indeed, the reported average value for ${ }^{\circ} \mathrm{Brix}$ in 'Imbú' pulp is below the required minimum value (Table 1). Fruits from cv. Ubá, widely accepted for industrial exploitation in Brazil, for example, presents a content of soluble solids ranging from 14-20 ${ }^{\circ}$ Brix (BENEVIDES et al., 2008; OLIVEIRA et al., 2013).Literature describes starch as the main carbon reserve used in post-harvest sucrose synthesis (the predominantly sugar in mature mango fruits) (BIALE; YOUNG, 1981). However, there is no consensus and further studies report that sucrose synthesis is not always temporally correlated with starch degradation (BERNARDES-SILVA et al., 2003). In any case, compared to other cultivars, cv. Imbú has a little percentage of starch on fruits and the lower reserve composition may be associated with the lower concentration of soluble solids. Silva et al. (2009), for example, found 1.1 e $3.5 \%$, respectively for cvs. Ubá and Tommy Atkins, while in average, only $0.5 \%$ was found for cv. Imbú.

TABLE 1- General characteristics of mango fruits from cv. Imbú. Fresh Weight (FW), firmness (F),\% seed (S), \% pulp (P),\% peel (Pe), ${ }^{\circ}$ Brix and \% starch (S).

\begin{tabular}{ccccccc}
\hline \multicolumn{7}{c}{ General characteristics } \\
\hline $\mathrm{FW}^{1}$ & $\mathrm{~F}$ & $\% \mathrm{~S}$ & $\% \mathrm{P}$ & $\% \mathrm{Pe}$ & ${ }^{\circ}$ Brix & $\%$ Starch \\
\hline 124.9 & 95.3 & 22.3 & 58.5 & 19.2 & 10.3 & 0.52 \\
\hline
\end{tabular}

${ }^{1}$ Average value from the four evaluated plants. $n=40$.

TABLE 2- Characterization of peel and pulp colors of mango fruits from cv. Imbú. The letters are indicative of the modules: $\mathrm{L}^{*}(L), \mathrm{a}^{*}(a), \mathrm{b}^{*}(b) \mathrm{C}^{*}(c)$ and the hue angle $\left(h^{\circ}\right)$.

\begin{tabular}{|c|c|c|c|c|c|c|c|c|c|}
\hline \multicolumn{5}{|c|}{ Fruit color } & \multicolumn{5}{|c|}{ Pulp color } \\
\hline$L^{1}$ & $a$ & $b$ & $c$ & $h^{\mathrm{o}}$ & $L$ & $a$ & $b$ & $c$ & $h^{\mathrm{o}}$ \\
\hline 54,94 & $-2,2$ & 22,49 & 22,83 & 95,04 & 69,14 & 4,05 & 49,16 & 49,47 & 85,69 \\
\hline
\end{tabular}

${ }^{1}$ Average value from the four evaluated plants. $n=40$. 


\section{CONCLUSION}

The morphological descriptors used allowed the rapid and efficient characterization of mango plants cv. Imbu and in view of the absence of most of the desirable characteristics for a mango fruit usable in industrial processes or for fresh consumption, it can be concluded that the fruits from cv. Imbu so far, are important for the production of rootstock.

\section{ACKNOWLEDGEMENT}

Financial support: Conselho Nacional de Desenvolvimento Científico e Tecnológico (CNPq) and Vale S.A.

\section{REFERENCES}

ANDRADE JÚNIOR, V.C. de; MALUF, W.R.; AZEVEDO, S.A. de; GOMES, L.A.A.; FARIA, M.A. Avaliação do potencial agronômico e da firmeza pós-colheita de frutos em híbridos de tomateiro. Ciência e Agrotecnologia, Lavras, v.25, n.3, p.489-502, 2001.

ANDRADE, P.F. de S. Fruticultura - análise da conjuntura agropecuária. Curitiba: Secretaria de Estado da Agricultura e do Abastecimento, 2012. (2)

\section{ARAÚJO, J.L. Propriedades termofísicas da polpa} do cupuaçu. 2001. 85 f. Dissertação (Mestrado em Engenharia Agrícola) - Universidade Federal da Paraíba, João Pessoa, 2001.

AZZOLINI, M.; JACOMINO, A.P.; SPOTO, M.H.F. Estádios de maturação e qualidade pós-colheita de goiabas 'Pedro Sato'. Revista Brasileira de Fruticultura, Jaboticabal, v.26, n.1, p.29-31, 2004.

BALLY, I.S.E. Advances in research and development of mango industry. Revista Brasileira de Fruticultura, Jaboticabal, v.33, n.1, p.57-63, 2011. Edição especial.

BENEVIDES, S.D.; RAMOS, A.M.; STRINGHETA, P.C.; CASTRO, V.C. Qualidade da manga e polpa da manga Ubá. Ciência e Tecnologia de Alimentos, Campinas, v.28, n.3, p.571-578, 2008.
BERNARDES-SILVA, A.P.F.; LAJOLO, F.M.; CORDENUNSI, B.R. Evolução dos teores de amido e açúcares solúveis durante o desenvolvimento e amadurecimento de diferentes cultivares de manga. Ciência e Tecnologia de Alimentos, Campinas, v.23, p.116-120, 2003.

BERNIZ, P.J. Avaliação industrial de variedades de manga (Mangifera indica L.) para elaboração de néctar. 1984. 57 f. Dissertação (Mestrado em Fitotecnia) - Universidade Federal de Viçosa, Viçosa, 1984.

BIALE, J.B.; YOUNG, R.E. Respiration and ripening of fruits-retrospect and prospect. In: FRIEND, L.; RHODES, M.J.C. (Ed.). Recent advances in the biochemistry of fruit and vegetables. London: Academic Press, 1981. p.1-39.

BUTAC, M.; MILITARU, M.; BUDAN, S. Criteria for harvesting plums at the optimum maturity for Romanian varieties of the fresh fruit market. Research Institute for Fruit Growing Pitesti. Fruit Growing Research, Romenia, v.28, n.1, 2012.

CASTRO NETO, M.T. de; CUNHA, G.A.P. da. Propagação e padrão da muda. In: MATOS, A.P. de (Org.). Manga: produção - aspectos técnicos. Brasília: Embrapa Comunicação para Transferência de Tecnologia, 2000. p.21-28.

COSTA, J.C.; SANTOS, C.A.F. Cultivo da mangueira: cultivares. 2004. Disponível em: $\leq$ cpatsa.embrapa.br/sistema produção/spmanga/ mercado.Htm>. Acesso em: 15 jun. 2005.

COSTA, W.S. da; SUASSUNA FILHO, J.; CAVALCANTI MATA, M.E.R.M.; QUEIROZ, A.J.M. Influência da concentração de sólidos solúveis totais no sinal fotoacústico de polpa de manga. Revista Brasileira de Produtos Agroindustriais, Campina Grande, v.6, n.2, p.141-147, 2004.

FAO - Food and Agriculture Organizational. FAO statistical yearbook 2013 - World Food and Agriculture. 2013. Disponível em: $\leq \mathrm{http}: / / \mathrm{www}$. fao.org/docrep/018/i3107e/i3107e03.pdf $>$. Acesso em: 28 set. 2015 .

FISCHER, I,H.; LOURENÇO, S.A.; AMORIM, L. Doenças pós-colheita em citros e caracterização da população fúngica ambiental no mercado atacadista de São Paulo. Tropical Plant Pathology, Brasília, v.33, n.3, p.219-226, 2008. 
GENÚ, P.J.C; PINTO, A.C.Q. A cultura da mangueira. Brasília: Embrapa Informação Tecnológica, 2002. 454p.

INTERNATIONAL BOARD FOR PLANT GENETIC RESOURCES. Descriptors for citrus. Rome: International Plant Genetic Resources Institute, 1988.27 p.

IPGRI - International Board for Plant Genetic Resources. Descriptors for mango (Mangifera indica L.). Rome: IPGRI, 2006. 71 p.

LAROUSSILHE, F. La manguier. Paris: Maisonneuve et Larose, 1980. 312 p.

LEDERMAN, I.E.; BEZERRA, J.E.F.; CARVALHO, P.S. de; ALVEZ, M.A.; SANTOS, V.F. dos. Determinação do ponto de colheita da manga Cv. Tommy Atkins, para a região semi-árida de Pernambuco. Revista Brasileira de Fruticultura, Jaboticabal, v.20, n.2, p.145-151, 1998.

LIMA NETO, F.P.L. Manga. Brasília: Agência de informação EMBRAPA, 2007. Disponível em: $\leq$ http://www.agencia.cnptia.embrapa.br/Agencia22/ AG01/Abertura.html>. Acesso em: jan. 2015.

MALCOLM, P.J.; HOLFORD, P.; MCGLASSON, W.B.; NEWMAN, S. Temperature and seed weight affect the germination of peach rootstock seeds and the growth of rootstock seedlings. Scientia Horticulturae, New York, v.98, p.247-256, 2003.

MARI, M.; CASALINI, L.; BARALDI, E.; BERTOLINI, P.; PRATELLA, G.C. Susceptibility of apricot and peach fruit to Monilinia laxa during phonological stages. Postharvest Biology and Technology, Amsterdam, v.30, p.105-109, 2003.

McCREADY, R.M.; GUGGOLZ, J.; SILVEIRA, V.; OWENS, H.S. Determination of starch and amylose in vegetables. Aplication to peas. Analytical Chemistry, Washington, v.22, n.9, p.1156-1158, 1950.

McGUIRE, R.G. Reporting of objective color measurements. HortScience, Alexandria, v.27, n.12, p.1254-1260, 1992.
OLIVEIRA, G.P.; SIQUEIRA, D.L. de; SILVA, D.F.P. da; MATIAS, R.G.P.; SALOMÃO, L.C.C. Caracterização de acessos de mangueira Ubá na Zona da Mata Mineira. Ciência Rural, Santa Maria, v.43, n.6, p.962-969, 2013.

PATEL, R.Z. A note on the seasonal variations in starch content of different parts of Coffea arabica trees. East African Agricultural and Forestry Journal, Nairobi, v.36, p.1-6, 1970.

RIBEIRO, I.C.N.S.; SANTOS, C.A.F.; NETO, F.P.L. Morphological characterization of mango (Mangifera indica) accessions based on brazilian adapted descriptors. Journal of Agricultural Science and Technology, Teerã, v.3, p.798-806, 2013.

RUFINI, J.C.M.; GALVÃO, E.R.; PREZOTTI, L.; SILVA. M.B.; PARRELLA, R.A.C. Caracterização biométrica e físico-química dos frutos de acessos de manga 'Ubá'. Revista Brasileira de Fruticultura, Jaboticabal, v.33, n.2, p.456-464, 2011.

SCHÄFER, G.; BASTIANEL, M.; DORNELLES, A.L.C. Porta-enxertos utilizados na citricultura. Ciência Rural, Santa Maria, v.31, p.723-733, 2001.

SCHMITZ, J.D.; PASA, M.S.; FISCHER, D.L.O.; FACHINELLO, J.C.; BIANCHI, V.J. Desempenho de porta-enxertos em diferentes sistemas de cultivo na produção de mudas do pessegueiro Chimarrita. Revista Ceres, Viçosa, MG, v.61, n.2, p.155-160, 2014.

SILVA, D.F.P.; SIQUEIRA, D.L.; PEREIRA, C.S.; SAlOMÃO, L.C.C.; STRUIVING, T.B. Caracterização de frutos de 15 cultivares de mangueira na Zona da Mata mineira. Revista Ceres, Viçosa, MG, v.56, n.6, p.783-789, 2009. 